Research Article

\title{
Competitive trait anxiety and general self- esteem of athletes according to the sport type and gender
}

Aleksandra A. Sanader ${ }^{1}$, Jelena R. Petrović ${ }^{凶} 2$ iD, Ljubica

Bačanac ${ }^{3}$, Ivan Ivković ${ }^{\text {, Ivan Petrović }}{ }^{\text {iD }}$ and Olivera M. Knezević 5

${ }^{1}$ Serbian Institute of Sport and Sport Medicine, Belgrade, Serbia

2 University of Defense, Military Academy, Belgrade, Serbia

${ }^{3}$ University of Donja Gorica, Faculty of Sport Management, Podgorica, Montenegro

${ }^{4}$ Ministry of Defense, Belgrade, Serbia

${ }^{5}$ University of Belgrade, Institute for Medical Research, Belgrade, Serbia

\section{ABSTRACT}

Traditionally, anxiety has been interpreted as a negative emotional state characterized by nervousness, worry, fret, uncertainty and vague fear which could have an adverse effect on sports achievement. On the other hand, sport type and its specific nature and demands, may also be connected with the level of state and trait anxiety. This study aimed to investigate potential differences in the competitive trait anxiety level and general self-esteem according to gender in sports of different contact level. The sample consisted of 1024 (590 males and 434 females) young athletes. Independent variables were sport contact level (non-contact, contact and collision sports) and gender. Dependent variables were measured by the adjusted versions of Sport Competition Anxiety Test and Rosenberg Self-Esteem Scale. Basic descriptive statistics was calculated for all the groups, and the differences between them were established using $\chi^{2}$ test and MANOVA. The results suggest significant differences in trait competitive anxiety per sport type, gender and their interaction, and no differences in the general self-esteem level. The current 
study reveals that not only the intensity but also the intergroup relationship of a sport contact level (non-contact, contact and collision sports) is gender determined. These findings are important in psycho-diagnostic procedure and choosing appropriate coping strategies for athletes.

Key words: aggression, combat sports, self - respect, sex, stress

UDK: 159.942:796.8

DOI: 10.19090/pp.2021.3.277-307

Received: 14.04.2021.

Revised: 27.08.2021.

Accepted: 09.09.2021.
Copyright @ 2021 The Author(s).

This is an open access article distributed under the terms of the Creative Commons Attribution License, which permits unrestricted use, distribution, and reproduction in any medium, provided the original author and source are credited.

${ }^{\bowtie}$ Corresponding author e-mail: jelenailicpetrovic@gmail.com 


\section{Introduction}

Anxiety is interpreted as a negative emotional state which has a negative impact on sports achievement (Weinberg \& Gould, 2007). Anxiety is caused by situations that are perceived as threatening because they threaten one's self-esteem, may cause personal harm, create uncertainty, create frustration (such as being unable to achieve goals), or create pressure (having to take a penalty shot to win a match). It involves fear, worry and doubt and it seems to be due to a lack of confidence in athletes own resources. In extreme cases, it can lead to shock, significantly changing the athlete's behavior, reducing concentration, and influencing movement control (Pijpers et al., 2003). Anxiety can be observed as trait, a permanent predisposition to see situations as threatening, or state, a temporary emotion in response to a situation (Spielberger, 1966). Also, it is important to mention that Martens et al. (1990) distinguish two ways of manifestation of anxiety in sport: somatic state anxiety (perceiving bodily symptoms such as sweaty palms, butterflies) and cognitive state anxiety (worry, concern, negative thoughts and expectations, fear of failure, poor concentration). A person with a high trait anxiety level perceives and experiences the competition as a stressful situation, manifests a higher anxiety level and responds with a disproportionally higher arousal level than a person with a lower anxiety level (Hardy et al. 1996). Gould et al. (1984) found that cognitive anxiety and perceived self-esteem are related to performance and competence expectations. Also, trait anxiety level can be related to motor abilities (Fasting, \& Gronningsaeter, 1986; Hayden et al., 1986; Heaps, 1978; Leonardson, \& Garguilo, 1978; Sanader et al., 2019).

General self-esteem is defined as the positive or negative attitude that a person has towards him/herself (Rosenberg et al., 1995). It is about the individual's opinion of oneself and how much he/she appreciates and respects himself/herself. Also, self-esteem can be defined as an individual's assessment which he/she usually maintains of him/herself, and expresses an attitude of approval or disapproval, and indicates if the individual feels him/herself capable, significant, successful and honorable (Coopersmith, 
1967). It significantly determines our values, our memories and memory processes, our interpretation of events, our evaluation standards and reference points, our goals, our choice of friends, spouse, groups, organizations, professions, and our environment in general (Rosenberg, 1965). Higher self-esteem indicates a positive appreciation of oneself: person take risks more courageously and do not set too high demands on him/herself; while low self-esteem means a poor opinion of one's own self and it is less likely to fight for his/her success (Baumeister et al., 2003). When a person has too little of it, he/she functions below his/her potential, and when he/she has too much of it, he/she acquires narcissistic personality traits (Bojanić et al., 2019). Individuals with high self-esteem deal better with failure compared to those with low self-esteem, feel happier in life, and have lower anxiety (Greenberg et al., 1992). Athletes with a high self esteem tend to believe they are capable, efficient and that the efforts they must invest will help them to develop and lead them to success. In addition, high self-esteem can help athletes to resist negative pressure (Connor, 1994) and allows them to perform better and be less anxious (Pruessner et al., 1999). On the contrary, athletes with low self-esteem, have little confidence in their skills and abilities, and maintain low expectations. Ichraf et al. (2013) found that males practicing team sports have a global self-esteem significantly higher than females, but in individual sports there is no significant difference between them. Many studies confirmed that general self-esteem significantly affects the people's behavior in sport contexts and is negatively associated with competitive anxiety (Bačanac et al., 2010; llić \& Ljubojević, 2011; Sari et al., 2013). Also, self - esteem can be related to motor abilities (Delignières et al., 1994; Fox \& Corbin, 1989).

Currently, the performance is the most predominant value in the vast majority of athletes. The importance of the result issues puts athletes under pressure. Whatever level of performance and experience in competitive sport is, competitive anxiety is omnipresent in athletes. It is part of the competition, training and everyday life routine of each athlete. In addition, the concerns of coaches are attached to results. Most of the time, 
coaches set victory as the main objective of training sessions, rather than helping the athlete to take advantage of the qualities that predispose him/her to give a better performance. It teaches an athlete it is important to win the opponent and to be better from him/her in every way. This deviation from the basic sense of the training can be a source of anxiety and stress, equally as the competition itself and importance of the achieved personal result. So, self-esteem can be threatened by the stressful situations encountered. This is why it seems particularly relevant to consider selfesteem in the model of anxiety and stress. High self-esteem can help athletes to withstand negative pressure (Connor, 1994), allows them to have better performance (Pruessner et al., 1999) and be less anxious. However, anxiety and stress and certain situations, difficult and threatening, could have an impact on the level of self-esteem (Langrock et al., 2002; Ritter et al., 2002). Subjects with high levels of anxiety also tend to have low selfesteem (Brustard \& Weiss, 1987; Brustard, 1988; Fasting \& Gronningsaeter, 1986; Hayden et al., 1986; Passer, 1983). It seems, therefore, that anxiety can have a short term impact on self-esteem, causing the individual problems. On the other hand, improvement, maintenance and protection of selfesteem are necessary so the individual can to deal effectively with certain episodes of anxiety and stress (Berjot et al., 2008; Crocker \& Park, 2004).

Lately, many sports have changed their rules of competitions to make them more attractive and create a more dynamic environment, and there has been rapid expansion and popularity of new martial arts with the intensive contact. They generally reduce the number of prohibited acts and permit greater degrees of destruction. All the above facts are reflected in greater demands of athlete's motor abilities, which has great impact on both physical (Sanader, 2005), and psychological characteristics of an athlete necessary to achieve sport success. Studies have shown that there are certain differences in the athletes' personality traits in non-contact and contact sports (Newcombe \& Boyle, 1995; Sohrabi et al., 2011). Some studies have shown that contact sports are positively associated with the amount of aggression in athletes (Silva, 1983; Tucker \& Parks, 2001). However, these 
findings were not confirmed by Keeler (2007). Finally, Martens et al. (1990) found that the objective characteristics of certain sports have an impact on the anxiety and emotional state of athletes.

Testing differences in anxiety among athletes of different contact levels is important since the collision in the modern sport is growing increasingly, even in sports where collisions are not allowed by the rules. Silva (1983) has differentiated three levels of contact in sport: collision (contact is necessary and integral to play; athletes hit or collide with great force - e.g., judo), contact (contact is legal and occurs incidentally, athletes routinely make contact with one another or inanimate objects but with less force than in collision sports - e.g., basketball), and non-contact (contact between opponents is not allowed - e.g., tennis). Although the current study cannot solve the dilemma of accuracy and completeness of this classification according to contact level, the problem researchers have to confront with should be mentioned. According to this criterion, karate is divided into two completely different disciplines and indeed it is rare that young athletes would compete in both kate and kumite (Korpanovski et al., 2011). Kate could be classified as non-contact sport, since it assesses the performance against imaginary opponents, and kumite belongs to collision sports. Although sport rules sanction collision contacts in football, handball and basketball, collisions are more frequent in these games - we have witnessed rougher starts and offenses that result in severe and serious injuries, for which the players are forced into a long recovery. Also, male lacrosse is marked as a collision sport and female lacrosse is marked as a contact sport, which means that gender and sport rules criteria are mixed (Acabchuk \& Johnson, 2017; Comstock et al., 2020; Putukian et al., 2014).

There have been a small number of studies examining the nature of the relationship between competitive anxiety and general self-esteem on one side, and sports contacts level and gender on the other (Bojanić et al. 2019). The complexity of the psychological phenomenon (Masten et al., 2006) and the relatively small number of women participating in collision sports might be one of the reason. According to the study of Aidar et al. 
(2018) sports activity may seem to be a tool to reduce the symptoms of anxiety: a positive significant relationship between anxiety trait and level of physical aggression and anger in contact sport athletes was found. According to Kunimatsu and Mersee (2012), there is a link between anxiety and the different forms, functions, and subtypes of aggression. A possible explanation may be that negative emotions, such anger, may lead to aggression (Berkowitz, 1989; Wyckoff, 2016). Pačesová and Šmela (2020) also showed a significant relationship between athletes' anxiety trait level and physical aggression. Stress, tension and anxiety can be manifested in socially appropriate way in dealing with sports with high level of body contact and physical aggression. On the other hand, high expectations, high level of perfectionism and too high level of motivation can cause anxiety which might have a negative impact on the performance, and that, in turn can cause failure or bad result, which further might negative impact on athlete's self - esteem and further performance and results. So, it is possible that sports youngsters, with lower levels of self-esteem, could behave more aggressively on the field and perhaps more successful in more aggressive sports, with higher level of body contact (combat, contact and collision), although findings of Bojanić et al. (2019) are not in line with this hypothesis.

Considering that specific sport activities might emphasize certain psychological characteristics of athletes (for example: aggressiveness in combat sports (Bojanić et al., 2019), athletes dark triade in team sports (Vaughan et al., 2019), pathology of body-image and eating disorders in aesthetic sports (Coelho et al., 2014) and that gender might also be an important factor for choice of sports activity (Koivula, 1995, 1999; Matteo, 1986; Metheny, 1965; Petrović, 2020; Rees et al., 1999; Riemer \& Visio, 2003), this study aimed to investigate potential differences in the competitive trait anxiety level and general self-esteem according to gender in non-contact, contact and collision sports. It was hypothesized that significant differences in both anxiety and self-esteem levels would be detected among male and female athletes competing in three sport contacts types. Particularly, the highest level of competitive anxiety will be present in female athletes in 
collision sport, along with low level of self - esteem and the lowest level of competitive anxiety will be present in female athletes in non - contact sport, along with high level of self-esteem. In male athletes, there was presumption that the highest level of competitive anxiety, and also selfesteem will be present in those athletes included in contact sports.

\section{Method}

\section{Participants}

The survey was carried out on a sample of 1024 athletes, 12-21 years of age (Table 1). Their sports experience varied within the range from 2 to 14 years of intensive involvement in sports. This data was not included in further processing since it was too heterogeneous to establish clear criteria: some athletes were included only in their sport for years, some of them were parallel included in two or more additional sports for years, some of them applied to participate in certain sport in the moment of testing for the first time. According to the contact level, 21 sports were divided into three groups: non-contact (track and field, badminton, bowling, karate kate, sailing, volleyball, dancing, swimming, table tennis, shooting, ice skating); contact (soccer, basketball, handball) and collision (judo, jiu jitsu, karate kumite, kick boxing, rugby, wrestling, savate, taekwondo). As shown in Table 1 , the sample included $20 \%$ less females than males. This difference is the most evident in collision sports. This data follows worldwide trends about less involvement of females in sport activities, especially those which are observed as gender inappropriate for some reason (Keeler, 2007; Pačesová \& Šmela, 2020). Also, within all three sport groups, the average age of girls, as well as the sport experience, was higher than of males. 


\section{Table 1}

Sample of subjects $(M \pm S D)$

\begin{tabular}{lccccc}
\hline Sport type & N & Male & Female & Age (years) & Sport experience (years) \\
\hline TOTAL & 1024 & 590 & 434 & $15.00 \pm 1.20$ & $7.13 \pm 2.55$ \\
Collision & 297 & 216 & 81 & $16.22 \pm 1.99$ & $8.23 \pm 2.80$ \\
Contact & 305 & 164 & 141 & $14.18 \pm 1.34$ & $6.26 \pm 1.98$ \\
Non-contact & 422 & 210 & 212 & $14.74 \pm 1.95$ & $6.99 \pm 2.46$ \\
\hline
\end{tabular}

Note: For Age and Sport experience in years, $M \pm S D$ are given

Instruments

The Sport Competition Anxiety Test (SCAT)

The Sport Competition Anxiety Test (SCAT) developed by Martens (1977) was used to measure competitive anxiety trait. It was originally designed for children and tested on 193 junior high school boys, aged 12-15. The SCAT has already been shown to have high test-retest reliability ( $r=0.77)$ (Weinber \& Gould, 2007). The participants responded using a three-point scale (hardly ever, sometimes and often). The test included fifteen questions, but only 10 scoring answers, so SCAT scores ranged from 10 to 30 . Items: 1 - "Competing against others is socially enjoyable", 4 - "I am a good sportsman when I compete", 7 - "Setting a goal is important when competing", 10 - "I like to compete in games that use a lot of physical energy" and 13 - "Team sports are more exciting than individual sports", were distractor questions, and items 6 and 11 were scored in reverse. Psychometric properties of SCAT for Serbian athletes have been established previously and scale's reliability was high $\alpha=.77$ (Lazarević \& Bačanac, 1984) and $\alpha=.83$ (Bačanac et al., 2011). Similar value of $\alpha=.82$ was obtained in the current study. Martens defined the competitive anxiety as the onedimensional concept, a stabile trait and predisposition, consisted of both somatic and cognitive component, but subsequent studies revealed its multidimensional nature (Burton, 1988), and new tests have been developed (Sanader et al., 2019). Still, studies have shown that the one-dimensional 
construct is a better predictor of success than individual components (Arendt \& Landers, 2003).

The 10-item Rosenberg Self-Esteem Scale (RSE)

The 10-item Rosenberg Self-Esteem Scale (RSE; Rosenberg, 1965) was used to assess self-esteem. In this instrument, the self-esteem was observed as the one-dimensional concept, a stabile trait and predisposition. Each response was scored along the 5-point scale, although the original instrument had had a four-tier scale. For the purposes of this study, it was adapted into a five-degree Likert scale anchored by 1 (strongly agree) to 5 (strongly disagree), and questions 2, 5, 6, 8, 9 were scored reversely. General self-esteem was represented by the sum of all item scores, providing a possible range from 10 to 50 . For the Serbian population, the language adaptation was done by Marić (2005) and the sample consisted of unemployed adults. The reliability of the scale was also reported $(\alpha=.80)$. A value of .73 has been found in the current study.

\section{Procedure}

The athletes were tested at one of The Summer Sports Training Camp organized by Ministry of Youth and Sport. Participants voluntarily registered to participate in different sports and because of that, number and gender of athletes was unequal between different sport types. Some sports were not offered as an option and also, there were some sports where only boys or girls were present. Also, for some camps and individuals testing was not approved. The athletes completed the tests in a group, in the presence of a psychologist. After being informed about the purpose of measuring and the confidentiality of the acquired data, athletes gave their consent and voluntarily completed the psychological inventory. Parents also gave their consent about underage children participation in different types of testing conducted on the camps, including motor, psychological and medical. 
Data analysis

Descriptive statistics - mean and standard deviation - were calculated for all variables. Distributions of SCAT and RSE scores were checked using Kolmogorov-Smirnov normality test, skewness and kurtosis. Skewness are less than \pm 1 and values of kurtosis were less than 3 , thus distribution might look like deviating from normal. However, our sample has $>1000$ subjects, distribution is unimodal and Kolmogorov-Smirnov test was not significant (both $\mathrm{p}$ values were $>.05$ ) thus, parametric statistical analyses were used. To check the significance of the data obtained in Table 1 , which were related to the sample characteristics, the procedure of the $\chi^{2}$ test was carried out. To explore the differences in the competitive trait anxiety level and general self-esteem according to gender and the sport contact groups (non-contact, contact and collision sports) MANOVA was used. Post hoc Scheffe test was used and effect size was assessed by partial eta squared with commonly used guidelines proposed by Cohen (1988). Statistical processing of the results was conducted with the statistical package SPSS 19.

Results

The descriptive results of the SCAT and RSE scores in relation to the sport type and the gender are presented in Table 2. Range on SCAT varied from Min $=10$ to $\operatorname{Max}=30$ and on RSE varied from Min $=22$ to $M a x=50$. Kolmogorov-Smirnov test for SCAT was 0.096 and for RSE 0.127. For SCAT Skewness was 0.54 and Kurtosis was -0.21 and for RSE Skewness was -0.98 and Kurtosis was 1.07. The results showed that there was a significant difference in terms of gender and type of sport distribution $\left(\chi^{2}=40.28, d f=\right.$ $2, p<.001)$, and the girls were significantly less engaged in collision sports. 
Table 2

Descriptive statistics of SCAT and RSE

\begin{tabular}{lcccc}
\hline \multirow{2}{*}{ Categories } & \multicolumn{2}{c}{ SCAT } & R & RSE \\
\cline { 2 - 5 } & $M$ & 4.10 & 43.13 & 4.92 \\
\hline Non-contact sports & 16.87 & 3.72 & 42.44 & 5.08 \\
Contact sports & 17.16 & 3.97 & 42.64 & 5.05 \\
Collision sports & 17.72 & 3.53 & 42.68 & 5.00 \\
\hline Male & 16.45 & 4.28 & 42.92 & 5.01 \\
Female & 18.23 & 3.96 & 42.78 & 5.00 \\
\hline TOTAL & 17.21 & & & \\
\hline
\end{tabular}

The results of MANOVA suggest significant differences in the SCAT results (Table 3$)$ according to the sport contact level $\left(F_{4,2034}=9.89, p<.001\right.$; Wilk's $\left.\lambda=.98, \eta p^{2}=.02\right)$, and gender $\left(F_{2,1017}=58.71, p<.001\right.$; Wilk's $\lambda=.94, \eta p^{2}$ $=.05)$ and also their interaction $\left(F_{4,2034}=4.13, p=.020\right.$; Wilk's $\left.\lambda=.99 \eta p^{2}=.01\right)$. Gender proved to be the most important predictor. The interaction effect suggests that the effect of gender on obtained SCAT results is not consistent across the different sports contact levels. In terms of general selfesteem, significant differences on the RSE have not been found $\left(F_{4,2034}=2.13\right.$, $p=.074)$ and because of it they were not detail discussed.

\section{Table 3}

MANOVA statistics for SCAT (dependent variable) and sport type and gender (independent variables)

\begin{tabular}{lccc}
\hline Factors & Ftest & $d f$ & $\eta p^{2}$ \\
\hline Sport type & $9.89^{* *}$ & 2 & 0.019 \\
Gender & $58.71^{* *}$ & 1 & 0.055 \\
Sport type * Gender & $4.13^{*}$ & 2 & 0.008 \\
\hline
\end{tabular}

Note: ${ }^{*} p<.05 ;{ }^{*} p<.01 ; \eta p^{2}$ - partial eta-squared 
The significant difference in competitive trait anxiety level was obtained between collision and non-contact sports $(p<.001)$. In Figure 1 depicts the results of the SCAT in relation to sport type and gender.

\section{Figure 1}

SCAT mean results according to the sport type and gender

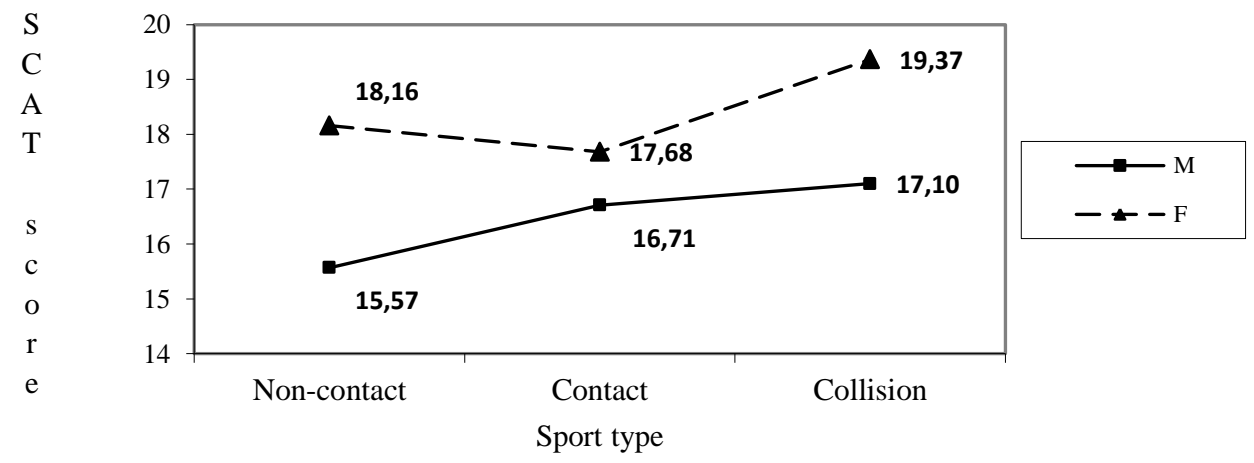

\section{Discussion}

Sports participation has positive effects on physical and biomechanical development, but also self-esteem, emotional regulation, anxiety of athletes (Lane \& Lovejoy, 2001; Manger \& Motta, 2005; Szuhany et al. 2015). Being involved in sports activity can also lead to the development of other competencies, new attitudes and perceptions, which can have a positive impact on self-esteem mainly mediated through children's sports self-image (Slutzky \& Simpkins, 2009). However, the diversity of sports necessarily points to the interplay between various sports and individual characteristics. In this research, trait of competitive anxiety and general self-esteem were used since they are personal predispositions which are stable over time. The assumption is that, under similar situations, athletes with certain level of these characteristic will react on the approximately similar manner. But, unlike self-esteem, which is comprehensive, competitive anxiety, is domain specific and relates only to sports field. So, there was an assumption that lower level of self-esteem 
might not be positively correlated with lower competitive anxiety. The results of some researchers showed negative correlation between selfesteem and anxiety (Huđin et al., 2020; Ischraf et al., 2013).

This study aimed to determine a difference in the competitive trait anxiety level and general self-esteem according to gender in non-contact, contact and collision sports. The hypothesis of significant differences in both anxiety and self-esteem level among male and female athletes competing in three sport contacts types was only partially confirmed. The differences were obtained for competitive anxiety trait but not for self-esteem trait. The main finding of this study was that within the same self-esteem level, athletes of both sex, engaged in different sport contact types vary in competitive trait anxiety level.

The highest competitive trait anxiety level was present in athletes engaged in collision sports, while the lowest was present in athletes from non-contact sports, which is consistent with foundings of Pfister (1976) and Ichraf et al. (2013). Previous studies have shown that strong emotions, even the negative ones such as anxiety, anger, rage and tension, can generate more energy, and thus enable the athletes to withstand a larger effort needed in situations of high collision (Cerin, 2003; Martin \& Gill, 1991; Ruiz \& Hanin, 2011). Also, it has been found that people with high level of competitive anxiety were more motivated to apply additional effort than those with low anxiety level (Wilson et al., 2007). Such type of motivation is particularly desirable in collision sports. Researchers have pointed out that high anxiety does not always block the sport performance, but in some situations, it can even improve it (Hanin, 2007; Kais \& Raudsepp, 2005; Masten et al., 2006). It might be that such situations are inherent to collision sports and therefore higher anxiety level may be a precondition for a successful participation for athletes since there was no difference in general self-esteem level between sport contacts types. It seems that athletes, participating in collision sports, perceive anxiety as a sign of willingness to perform, which was shown by Feltz (1988). Athletes in non-contact sports perceive increased arousal, before a sport event, as a fear and as a state in 
which they cannot perform successfully, so low trait anxiety is more desirable.

The results of the currents study suggest that the girls are significantly less engaged in collision sports. The increase in participation of females in collision sports has been observed over the past two decades (e.g., since 2004, women have participated in regular Olympic Program in wrestling disciplines), so the differences in the specific requirements related to gender are increasingly smaller (Keeler, 2007). However, gender psychological differences, contrary to the official norms, still exist. In fact, the research confirms that gender, in addition to the level of contact between athletes, contributes to the differences in competitive trait anxiety. The differences between male and female athletes, in competitive trait anxiety level, are present in all three sport groups, and confirm that male athletes are generally less anxious. Jones et al. (1991) explain this difference by the attribution of causality: anxiety in men largely forms under the influence of perceived strengths and abilities of the opponents, and the likelihood of achieving the victory, while the anxiety and self-confidence among women are most affected by their own sense of readiness and certainty of good quality performance and the importance they themselves attach to it. Generally, there is cultural causality, but genetic determination might be crucial in gender anxiety differences. The consistency of the gender differences, in terms of competitive trait anxiety, has been shown by the data obtained from young athletes, showing that age has no bearing on the anxiety level (Rose Júnior \& Vasconcellos, 1997).

Meanwhile, it is interesting that the level of anxiety in male athletes is increasing with contact level, while in female group relation is different. It means that type of sport, i.e., contact level in the sport in which athlete is included can, together with gender modification level of sport competition anxiety, since in this research the lowest competitive trait anxiety level is present in male athletes engaged in non-contact sports, while the highest is in those ones in collision sports. This is opposite to the results of that males are more anxious than females in both individual and collective sports 
(Anderson \& Williams, 1987) although in the same research was founded that females expressed more cognitive anxiety and males show more somatic anxiety (Ischer et al. 2013). Our hypothesis about highest level of competitive anxiety and self-esteem among male athletes in contact sports was not confirmed. It seems that close and intensive physical contact with opponent(s) makes male athletes in collision sports more anxious, nervous and perhaps frets and concerned about not being declared as cowards if they windrow direct physical contact, punches or other form of aggressive behavior. And, of course, there is a link with gender expectations and masculine rules of behavior in sports, both internal and external (Koivula, 1995, 1999; Visek et al., 2010) and injury treat (Lane et al.,, 2012).

On the other hand, although female athletes engaged in collision sport are most anxious, those engaged in contact sports are least anxious (even though their lowest anxiety level is still higher than the highest results in male athletes who are engaged in collision sports). These relations need further examination, since our hypothesis about the presence of the highest level of competitive anxiety in female athletes in collision sport, and the lowest level of competitive anxiety in female athletes in non - contact sport, was confirmed only partially. The possible explanation might be that contact sports are perceived as a kind of safety zone by female, where there are clear rules about kind and level of manifestation of appropriate aggressive behavior, where aggressiveness is used only in instrumental purposes (not with intention of deliberately hurting of opponent) and third side (judges) decisions have the main role. Also, different researches about kind and level of aggressive behavior in sport constantly reported lower level of aggressiveness and more use of non-physical forms of aggressive behavior among female athletes than males. And of course, gender biases towards appropriate kinds of sports for girls and females and expectances about their physical appearance and manners of (sports) behavior, may also have a part (Visek et al., 2010). Female athletes in collision sports due to this can be exposed to additional pressure to fit the standards about desirable female 
body shape (Bowker, 2006; Ouyang et al., 2019) and way of behavior on the court and out of it (Koivula et al., 2002).

Also, interaction effect although weak, suggests that there is different effect of gender on level of sports' anxiety: obtained SCAT results are not consistent across the different sports according to contact level. The possible explanation might be the nature of contact and rules of the exact sport, but also expectations of public from competitors. Non-contact sports are based on expectation of omission of direct physical contact between competitors, so anxiety might be prescribed only to the level of preparedness of competitors, since non-contact sports are mostly individual. The biggest gender differences between results in level of sports anxiety are present here. On the other hand, the smallest difference between genders was detected in anxiety in the field of contact sports. Anxiety level is the lowest in male athlete sample and mild in female sample. In case of males, the explanation might be responsibility for achieved results which is perceived as equally distributed among members of equip and different roles and duties in the team. In the case of female athletes, the level of sports anxiety is higher than in non - contact sports, but it is still smaller than in collision sports. The reason might be an opportunity of using apologetic behaviors among female athletes. Female apologetic behavior is when female athletes 'apologize' for participating in sport by overemphasizing their femininity through clothing choice, physical appearance, self-expression, and style of athletic play. Female athletes "are always framed by their status as both athletes and women": men can succeed and be publicly recognized as 'just an athlete', while women cannot solely have an athletic identity: it must be overshadowed by either their physical appearance or care giving abilities, which gives the illusion that female athletic accomplishments are not valid and not good enough and combating the issue that female athletes' appearance and uniforms attract more attention than their performances.

Femininity can be defined as a socially constructed concept that states how women should look, act, and what they should value (Hardy, 
2015). Higher level of socially constructed concept is represented by hegemonic femininity - the sociologically "correct" version of women, defined by traits such as submissiveness, dependency, concern over physical appearance and emotional ability (Hardy, 2015). Sports participation is associated with masculine traits, such as aggression, strength, power, dominance, and violence. In sports, it is not expected from female athletes to show high level of direct physical aggression, nor to have masculine body shape or to behave as a male, so they have to make compensation of gender inappropriate activity with feminine emphasized details like nails, hair, dressing, etc. (since rough and direct physical contact present in collision sports implies absence of any female gadgets, like jewelry, make up, fashion details, etc.). Also, collision sports presume some deviations from ideal female body shape. On the other hand, male athletes have a big pressure from failure in sports based on typically expected male physical attributes. So the difference in pressure which creates anxiety is different between genders, according to the sports contact level: male athletes feel pressure to be the best and socially worth in its own field, and female athletes have different kind of problem: how to be successful on visiting field but still be perceived as "correct" version of women in sports whose hyper masculine aggressive nature is reserved for men, since specifically in collision sports, their sexuality is questioned. The results of interaction in this research are consisted with those of Davis-Delano et al. (2009) that softball female players are engaged in more apologetic behavior than soccer and basketball players. Also, Davis-Delano et al. (2009) and Grossman (2017) claims that female apologetic behavior is more visible in elite level sport because of commercialization and media portrayal. However, this behavior exists in all levels of sport.

Limitation of this research was the method classifying for sport types, e.g., football and basketball were classified as contact sports, even though they contain many elements of the collision. Another uncontrolled sport categorization was present in this study as well. The most of the noncontact sports represents individual sports. In those, the athlete relies only 
on his/her own capacity and abilities. Kirby and Liu (1999) found that athletes engaged in team sports (e.g., basketball) were more anxious and less self-confident than athletes in individual sports (e.g., athletics), regardless of gender. Wong et al. (1993) found that the competition trait anxiety was more pronounced in female athletes engaged in individual sports and that their self-confidence is lower than in athletes in team sports. This has been attributed to the diffusion of responsibility in team sports. Limitations could also be related to the applied instrument. SCAT is onedimensional test and observes intensity but not the direction of competitive trait anxiety measures. Restrictive factors also might be wide range of age and especially even wider range of sports' experience in our sample. Some other reasons for omitting relationship between competitive anxiety, and insignificance of self-esteem in terms of gender and sport type can be moderator variables, like levels of sports success and perfectionism (Gotwals et al., 2003; Koivula et al., 2002) physical competence (Bowker, 2006), self-efficacy (Ouyang et al., 2019), motivation (Chantal et al., 2005) which opens an avenue for further empirical endeavors on the interplay of these characteristics and involvement in contact and non-contact sports.

\section{Conclusion}

This research shows, that gender and the sport contact type, but also their interaction, may contribute to the differences in the competitive trait anxiety level, since some data about anxiety in terms of individual and team sports reveals that male athletes are more anxious than female (Anderson \& Williams, 1987; Bojanić et al., 2019; Ichraf et al., 2013). These research did not take into account body contact level and potential aggressiveness caused by the nature of certain sport. It should be emphasized that the results of this research showed that high anxiety, which could negatively affects performance, does not apply in all sports, especially not to such a high degree as in contact and collision sports where contact is intense and permanently present, and requires optimal, relatively high level of athlete's excitement, far more than in non-contact sports. 
Actually, the result that gender is the most significant factor is consequence of the fact that there are a small number of females that participate in sports' activities in Serbia, especially in collision sports compared to male athletes. Also, when it comes to the research of differences in general selfesteem, it is necessary to take into account other factors because gender and sport contact level, are not the only factors that contribute to the individual differences in the level of general self-esteem of athletes. The link between anxiety and self-esteem, and self-esteem and contact level detected in some others researches (Ichraf et al., 2013) was not confirmed dispute findings of Huđin et al. (2020) that self-esteem was higher in noncontact sports athletes, so further investigation of self-esteem in athletes would be recommended. Our findings on self-esteem are in line with the results of the study of Bojanić et al. (2019) and explanation might be potential link between self-esteem and mediator factors such as aggression (Donnellan et al., 2005). Finally, we may propose further research on whether a higher level of anxiety among athletes in collision sports should be linked to negative effect on sports performance, as there was no difference between groups in the self-esteem. Or, should we look for the causes in the very nature of the collision.

Conflict of interest

We have no conflicts of interest to disclose.

\section{Data availability statement}

For further details on data contact the authors of the manuscript.

\section{References}

Acabchuk, R. L., \& Johnson, B. T. (2017). Helmets in women's lacrosse: what the evidence shows. Concussion, 2(2), CNC39. https://doi.org/10.2217/cnc2017-0005

Aidar, F. J., Jacó de Oliviera, R., Chilibeck, P. D., de Souza, R. F., Carneiro, A. L., \& Machado-Reis, V. (2018). A randomized trial of the effects of an aquatic exercise program on depression, anxiety levels, and functional capacity of 
people who suffered an ischemic stroke. Journal of Sports Medicine and Physical Fitness, 58(7-8), 1171-1177. https://doi.org/10.23736/s00224707.17.07284-X

Anderson, M.B., \& Williams, J.M. (1987). Gender role and sport competition anxiety: A re-examination. Research Quartely for Exercise and Sport, 58(1), 52-56. https://doi.org/10.1080/02701367.1987.10605420

Arent, S.M., \& Landers, D.M. (2003). Arousal, Anxiety, and Performance: A Reexamination of The Inverted-U Hypothesis. Research Quarterly for Exercise and Sport, 74(4), 463-444. https://doi.org/10.1080/02701367.2003.10609113

Bačanac, Lj., Kitanović, V., Nikolić, M., Ćirković, T., \& Ilić, J. (2011). Psihometrijske karakteristike i norme za testove: SCAT, SCl, ACSI-28 and GSE. [Psychometric Properties And Norms For The Tests: SCAT, SCI, ACSI-28 and GSE]. Unpublished material. Belgrade: Serbian Institute of Sport and Sports Medicine.

Bačanac, Lj., Nikolić, M., \& llić, J. (2010). Odnos sportskog samopouzdanja sa demografskim, situacionim i psihološkim kakarteristikama sportista [SelfConfidence Relationship with Demographic Situation and Psychological Characteristics of Athlete]. In R. Stanković (Ed.), XIV međunarodni naučni skup "FIS komunikacije 2010 u sportu, fizičkom vaspitanju i rekreaciji", (pp. 245-257), Niš: Univerzitet u Nišu, Fakultet sporta i fizičkog vaspitanja.

Baumeister, R.F., Campbell, J.D., Krueger, J.I, \& Vohs, K.D. (2003). Does High SelfEsteem Cause Better Performance, Interpersonal Success, Happiness, or Healthier Lifestyles? Psychological Science in the Public Interest, 4(1), 144. https://doi.org/10.1111/1529-1006.01431

Berjot, S., Girault-Lidvan, N., \& Battaglia, N. (2008). Stress et faire face à la stigmatisation et à la discrimination : vers un modèle du faire face aux menaces du l'identité. In S. Berjot \& B. Paty (Eds.), Stress et faire face aux menaces du soi et de l'identité (pp. 235-276). Reims: Editions et Presses Universitaire de Reims.

Berkowitz, L. (1989). Frustration-aggression hypothesis: Examination and reformulation. Psychological Bulletin, 106(1), 59-73. https://doi.org/10.1037/0033-2909.106.1.59

Bojanić, Ž., Nedeljković, J., Šakan, D., Mitić, P.M., Milovanović, I., \& Drid, P.(2019). Personality traits and self - esteem in combat and team sports. Frontiers in Psychology, 10 (2280), 1-10. https://doi.org/10.3389/fpsyg.2019.02280 
Bowker, A. (2006). The relationship between sports participation and selfesteem during early adolescence. Canadian Journal of Behavioural Science/Revue canadienne des sciences du comportement, 38(3), 214229. https://doi.org/10.1037/cjbs2006009

Brustad, R. J. \& Weiss, M. R. (1987). Competence perceptions and sources of worry in high, medium and low competitive traitanxious young athletes. Journal of Sport Psychology, 9(2), 97-105. https://doi.org/10.1123/jsp.9.2.97

Brustad, R.J. (1988). Affective outcomes in competitive youth sports: The influence of intrapersonal and socialization factors. Journal of Sport and Exercise Psychology, 10(3), 307-321. https://doi.org/10.1123/jsep.10.3.307

Burton, D. (1988). Do Anxious Swimmers Swim Slower? Re-Examining the Elusive Anxiety-Performance. Journal of Sport Psychology, 10(1), 45-61. https://doi.org/10.1123/jsep.10.1.45

Cerin, E. (2003). Anxiety versus Fundamental Emotions as Predictors of Perceived Functionality of Pre-Competitive Emotional States, Threat, and Challenge in Individual Sports. Journal of Applied Sport Psychology, 15(3), 223-238. https://doi.org/10.1080/10413200305389

Chantal, Y., Robin, P., Vernat, J. P., \& Bernache-Assollant, I. (2005). Motivation, sportspersonship, and athletic aggression: a mediational analysis. Psychology of Sport and Exercise, 6(2), 233-249. https://doi.org/10.1016/.jpsychsport.2003.10.010

Coelho, G. M., Gomes, A. I., Ribeiro, B. G., \& Soares, E. (2014). Prevention of eating disorders in female athletes. Open access journal of sports medicine, 5, 105-113. https://doi.org/10.2147/OAJSM.S36528

Cohen, J. (1988). Statistical Power Analysis for the Behavioral Sciences (2nd ed.). Hillsdale, NJ: Lawrence Erlbaum Associates, Publishers.

Comstock, R. D., Arakkal, A. T., Pierpoint, L. A., \& Fields, S. K. (2020). Are high school girls' lacrosse players at increased risk of concussion because they are not allowed to wear the same helmet boys' lacrosse players are required to wear?. Injury Epidemiology, 71), 1-10. https://doi.org/10.1186/s40621-020-00242-5

Connor, M. J. (1994). Peer relations and peer pressure. Association of Educational Psychologists Journal, 9(4), 207-215.

https://doi.org/10.1080/0266736940090403 
Coopersmith, S. (1967). The antecedents of self-esteem. San-Francisco: W.H. Freeman.

Crocker, J., \& Park, L. E. (2004). The costly pursuit of self-esteem. Psychological Bulletin, 130 (3), 392-414. https://doi.org/10.1037/0033-2909.130.3.392

Davis-Delano, L.R., Pollock, A., \& Ellsworth Vose, J. (2009). Apologetic Behavior among Female Athletes: A New Questionnaire and Initial Results. International Review for the Sociology of Sport, 44(2-3), 131-150. https://doi.org/10.1177/1012690209335524

Delignières, D., Marcellini, A., Legros, P. \& Brisswalter, J. (1994). Self-perception of fitness and personality traits. Perceptual and Motor Skills, 78(3), 843-851. https://doi.org/10.2466/pms.1994.78.3.843

Donnellan, M. B., Trzesniewski, K. H., Robins, R. W., Moffitt, T. E., \& Caspi, A. (2005). Low self-esteem is related to aggression, antisocial behavior, and delinquency. Psychological science, 16(4), 328-335. https://doi.org/10.1111/j.0956-7976.2005.01535.x

Fasting, K., \& Gronningsaeter, H. (1986). Unemployement, trait anxiety and physical exercise. Scandinavian Journal of Sports Science, 8(3), 99-103. https://doi.org/10.1111/j.1600-0838.1992.tb00329.x

Feltz, D. L. (1988). Self-confidence and Sports Performance. In K. B. Pandolf (Ed.), Exercise and Sport Sciences Reviews (pp. 423-457). New York: MacMillan. https://doi.org/10.1249/00003677-198800160-00016

Fox, K.H. \& Corbin, C.B. (1989). The Physical Self-Perception Profile: Development and preliminary validation. Journal of Sports and Exercise Psychology, 17(4), 408-430. https://doi.org/10.1123/jsep.11.4.408

Gotwals, J. K., Dunn, J. G., \& Wayment, H. A. (2003). An examination of perfectionism and self-esteem in intercollegiate athletes. Journal of Sport Behavior, 26(1), 17-38. https://doi.org/10.1016/i.paid.2004.09.009

Gould D., Petchlikoff L., \& Weinberg R.S. (1984). Antecedents of, temporal changes in, and relationships between the CSAI-2 subcomponents. Journal of Sport Psychology, 6(3), 289-304.

https://doi.org/10.1123/jsp.6.3.289

Greenberg, J., Solomon, S., Pyszczynski, T., Rosenblatt, A., Burling, J., Lyon, D., Simon, L., \& Pinel, E. (1992). Why do people need self-esteem? Converging evidence that self-esteem serves an anxiety-buffering function. Journal of 
Personality and Social Psychology, 63(6), 913-922.

https://doi.org/10.1037/0022-3514.63.6.913

Grossman, J. L. (2017). Nine to five: how gender, sex and sexuality continue to define the American workplace. Cambridge University Press.

Hanin, Y. (2007). Emotions in Sport: Current Issues and Perspectives. In G. Tenenbaum \& R. C. Eklund (Eds.), Handbook of Sport Psychology, 3rd ed. (pp. 31-58). Hoboken, NJ: John Wiley \& Sons.

Hardy, E. (2015). The female 'apologetic' behavior within Canadian women's rugby: athlete perceptions and media influences. Sport in Society, 18(2), 155-167. https://doi.org/10.1080/17430437.2013.854515

Hardy, L., Jones, G., \& Gould, D. (1996). Understanding Psychological Preparation for Sport. UK: Wiley.

Hayden, R. A., Allen, G. J., \& Camaione, D. N. (1986). Some psychological benefits resulting from involvement in an aerobic fitness program from the perspective of participants and knowledgeable informants. Journal of Sports Medicine, 26(1), 67-76.

Heaps, R. A. (1978). Relating physical and psychological fitness: a psychological point of view. Journal of Sports Medicine, 18(4), 399-408.

Huđin, N., Glavaš, D., \& Pandžić, M. (2020). Contact sports as a sport of more aggressive athletes?. Tims. Acta, 14(1), 5-16. https://doi.org/ 10.5937/timsact14-27343

Ichraf, A., Baccouche, M. A., Trabelsi, K., Masmoudi, L., \& Elloumi, A. (2013). Effect of gender and type of sport on anxiety and self-esteem. International Journal of Humanities and Social Science Invention, 2(3), 55-61.

Ilić, J. \& Ljubojević, M. (2011): Comparison of self-esteem, athletic identity and motivation of basketball players. In S. Simović (Ed.), 3. International Scientific Congress Anthropological aspects of sports, physical education and recreation, Proceeding book, (pp. 105-112). Banja Luka: Faculty of Sport and Physical Education.

Jones, G., Swain, A.B.J., \& Cale, A. (1991). Gender Differences in Pre Competition Temporal Patterning and Antecedents of Anxiety and Self Confidence. Journal of Sport and Exercise Psychology, 13(1), 1-15. https://doi.org/10.1123/jsep.13.1.1 
Kais, S., \& Raudsepp, L. (2005). Intensity and Direction of Competitive State Anxiety, Self-Confidence and Athletic Performance. Kinesiology, 371), 1320.

Keeler, L.A. (2007). The Differences in Sport Aggression, Life Aggression, and Life Assertion among Adult Male and Female Collision, Contact, and Noncontact Sport Athletes. Journal of Sport Behavior, 30(1), 57-77.

Kirby, R.J., \& Liu, J. (1999). Precompetition Anxiety in Chinese Athletes. Perceptual and Motor Skills, 88(1), 297-303. https://doi.org/10.2466/pms.1999.88.1.297

Koivula, N. (1995). Ratings of gender appropriateness of sports participation: Effects of gender based schematic processing. Sex Roles, 33(7-8), 543557. https://doi.org/10.1007/bf01544679

Koivula, N. (1999) Sport participation: differences in motivation and actual participation due to gender typing. Journal of Sport Behavior, 22(3), 360380.

Koivula, N., Hassmén, P., \& Fallby, J. (2002). Self-esteem and perfectionism in elite athletes: Effects on competitive anxiety and selfconfidence. Personality and individual differences, 32(5), 865-875. https://doi.org/10.1016/s0191-8869(01)00092-7

Koropanovski, N., Berjan, B., Bozić, P., Pažin, N., Sanader, A., Jovanović, S., \& Jarić, S. (2011). Anthropometric and Physical Performance Profiles of Elite Karate Kumite and Kata Competitors. Journal of Human Kinetics, 30, 107-114. https://doi.org/10.2478/v10078-011-0078-x

Kunimatsu, M. M., \& Mersee, M. A. (2012). Examining the presence of anxiety in aggressive individuals: The illuminating role of fight-or-flight mechanisms. Child \& Youth Care Forum, 41(3), 247-258. https://doi.org/10.1007/s10566$\underline{012-9178-6}$

Lane, A. M., \& Lovejoy, D. J. (2001). The effects of exercise on mood changes: the moderating effect of depressed mood. Journal of sports medicine and physical fitness, 41(4), 539-545.

Lane, A. M., Beedie, C. J., Jones, M. V., Uphill, M., \& Devonport, T. J. (2012). The BASES expert statement on emotion regulation in sport. Journal of Sports Sciences, 30(11), 1189-1195. https://doi.org/10.1080/02640414.2012.693621

Langrock, A. M., Compas, B. E., Keller, G., Merchant, M. J., \& Copeland, M. E. (2002). Coping with the stress of parental depression: Parents' reports of 
children's coping, emotional, and behavioral problems. Journal of Clinical Child and Adolescent Psychology, 37(3), 312-324.

Lazarević, Lj., \& Bačanac, Lj. (1984). Metodološke osnove psihološkog ispitivanja sportista [Methodological Foundations of Psychological Study of Athletes]. In: Unifikacija testova i metodologije testiranja vrhunskih sportista. Belgrade: JZFKMS

Leonardson, G.R., \& Garguilo, R.A. (1978). Self-perception and physical fitness. Perceptual and Motor Skills, 46(1), 338. https://doi.org/10.2466/pms.1978.46.1.338

Manger, T. A., \& Motta, R. W. (2005). The impact of an exercise program on posttraumatic stress disorder, anxiety, and depression. International Journal of Emergency Mental Health, 71), 49-57.

Marić, Z. (2005). Predikcija intenziteta i namere traženja posla na uzorku nezaposlenih [Predicting Job - Seeking Intensity and Job - Seeking Intention In The Sample of Unemployed]. Psihologija, 38(2), 181-195.

Martens, R. (1977). The Sport Competition Anxiety Test. Champaign, IL: Human Kinetics.

Martens, R., Burton, D., Vealey, R., Bump, L., \& Smith, D. (1990). The Competitive State Anxiety Inventory-2 (CSAI-2). In R. Martens, R. S. Vealey, \& D. Burton (Eds.), Competitive Anxiety in Sport. (pp. 117-190). Champaign, IL: Human Kinetics.

Martin, J. J., \& Gill, D. L. (1991). The Relationships among Competitive Orientation, Sport-Confidence, Self- Efficacy, Anxiety and Performance. Journal of Sport and Exercise Psychology, 13(2), 149-159. https://doi.org/10.1123/jsep.13.2.149

Masten, R., Tušak, M., \& Faganel, M. (2006). Impact of Identity on Anxiety in Athletes. Kinesiology, 38(2), 126-134. https://doi.org/10.1037/e548052012$\underline{583}$

Matteo, S. (1986). The effect of sex and gender-schematic processing on sport participation. Sex Roles, 15, 417-432. https://doi.org/10.1007/bf00287981

Metheny, E. (1965). Symbolic forms of movement: The feminine image in sports. In E. Metheny (Ed.), Connotations of movement in sport and dance (pp. 43-56). Dubuque, IA: Brown. 
Newcombe, P.A., \& Boyle, G.J. (1995). High School Students' Sports Personalities: Variations across Participation Level, Gender, Type of Sport, and Success. International Journal of Sport Psychology, 26, 277-294.

Ouyang, Y., Wang, K., Zhang, R. T., Peng, L., Song, G., \& Luo, J. (2019). The influence of sports participation on body image, self-efficacy and self-esteem in college students. Frontiers in psychology, 10(3039), 1-10. https://doi.org/10.3389/fpsyg.2019.03039

Pačesová, P., \& Šmela, P. (2020). Aggression and anxiety trait level of young male contact and non-contact athletes. Acta Gymnica, 50(1), 9-15. https://doi.org/10.5507/ag.2020.001

Passer, M. W. (1983). Fear of failure, fear of evaluation, perceived competence, and self-esteem in competitive traitanxious children. Journal of Sport Psychology, 5 (2), 172-188. https://doi.org/10.1123/jsp.5.2.172

Petrović, J. (2020). Importance of Sex and Gender for University Sports. In M. Bobrik, B. Antala, \& R. Pelucha. (Eds.), Physical education in Universities: Researches - Best Practices - Situation (pp. 73-82). Bratislava, Slovakia: Slovak Scientific Society for Physical Education and Sport and FIEP.

Pfister, R. (1976). Psychophysiologie, agressivité et sport. Annales de l'ENSEPS, 10, 72-77.

Pijpers, J. R., Oudejans, R. R. D., Holsheimer, F., \& Bakker, F. C. (2003). AnxietyPerformance Relationships in Climbing: A Process-Oriented Approach. Psychology of Sport and Exercise, 4(3), 283-304. https://doi.org/10.1016/s1469-0292(02)00010-9

Pruessner, J. C., Hellhammer, D. H., \& Kirschbaum, C. (1999). Low self-esteem, induced failure and the adrenocortical stress response. Personality and Individual Differences, 27(3), 477-489. https://doi.org/10.1016/s01918869(98)00256-6

Putukian, M., Lincoln, A. E., \& Crisco, J. J. (2014). Sports-specific issues in men's and women's lacrosse. Current Sports Medicine Reports, 13(5), 334-340. https://doi.org/10.1249/jsr.0000000000000092

Rees, R., Brandel-Bredenbeck, H., \& Brettschneider, W. (1999). Globalizing gender: A study of sports stereotyping among German and American adolescents. International Sports Studies, 27(1), 5-22. 
Riemer, B. A., \& Visio, M. E. (2003). Gender typing of sports: An investigation of Metheny's classification. Research Quarterly for Exercise and Sport, 74(2), 193-204. https://doi.org/10.1080/02701367.2003.10609081

Ritter, J., Stewart, M., Bernet, C., Coe, M., \& Brown, S. A. (2002). Effects of childhood exposure to familial alcoholism and family violence on adolescent substance use, conduct problems, and self-esteem. Journal of Traumatic Stress, 15 (2), 113-122. https://doi.org/10.1023/A:1014803907234

Rose Júnior, D., \& Vasconcellos, E.G. (1997). Ansiedade-Traçocompetitiva E Atletismo: Um Estudo Com Atletasinfanto-Juvenis. Revista Paulista de Educação Física, 11(2), 148-154.

Rosenberg, M. (1965). Society And The Adolescent Self-Image. Princeton, NJ: Princeton University Press.

Rosenberg, M., Schooler, C., Schoenbach, C., \& Rosenberg, F. (1995). Global SelfEsteem and Specific Self-Esteem: Different Concepts, Different Outcomes. American Sociological Review, 60(1), 141-156.

Ruiz, M.C., \& Hanin, Y.L. (2011). Percieved Impact of Anger on Performance of Skilled Karate Athletes. Psychology of Sport and Exercise, 12(3), 242-249. https://doi.org/10.1016/j.psychsport.2011.01.005

Sanader, A. (2005): Ritmička gimnastika - modelne karakteristike gimnastičarki. [Rhythmics Gymnastics - Model Characteristics of Female Gymnasts]. Beograd: Zadužbina Andrejević.

Sanader, A. A., Bačanac, L., Orlić, A., Knezevic, O. M., Ivkovic, l., \& Ugarkovic, D. (2019). Factorial validity of extended sport competitive anxiety test evaluated with young athletes. South African Journal for Research in Sport, Physical Education and Recreation, 47(1), 121-131.

Sari, l., Ilić, J., \& Ljubojević, M. (2013). The Comparison of Task and Ego Orientation and General Self-Esteem of Turkish and Montenegrin Young Basketball Players. Kinesiology, 45(2), 203-212.

Silva, J. M. (1983). The Perceived Legitimacy of Rule Violating Behavior in Sport. Journal of Sport Psychology, 5, 438-448. https://doi.org/10.1123/jsp.5.4.438

Slutzky, C. B., \& Simpkins, S. D. (2009). The link between children's sport participation and self-esteem: Exploring the mediating role of sport selfconcept. Psychology of Sport and Exercise, 10(3), 381-389. https://doi.org/10.1016/.jpsychsport.2008.09.006 
Sohrabi, F., Atashak, S., \& Aliloo, M. (2011). Psychological Profile of Athletes in Contact and Non-Contact Sports. Middle-East Journal of Scientific Research, 9(5), 638-644.

Spielberger, C. D. (1966). Theory and research on anxiety and behavior. New York: Academic press.

Szuhany, K. L., Bugatti, M., \& Otto, M. W. (2015). A meta-analytic review of the effects of exercise on brain-derived neurotrophic factor. Journal of psychiatric research, 60, 56-64. https://doi.org/10.1016/j.jpsychires.2014.10.003

Tucker, L. W., \& Parks, J.B. (2001). Effects of Gender and Sport Type on Intercollegiate Athletes' Perceptions of the Legitimacy of Aggressive Behaviors In Sport. Sociology of Sport Journal, 18(4), 403-413. https://doi.org/10.1123/ssj.18.4.403

Vaughan, R., Madigan, D. J., Carter, L. C. \& Nicholls, A.R. (2019). The Dark Triad in Male and Female Athletes and Non-Athletes: Group Differences and Psychometric Properties of the Short Dark Triad (SD3). Psychology of Sport and Exercise, 43(4), 64-72. https://doi.org/10.1016/j.psychsport.2019.01.002

Visek, A. J., Watson, J. C., Hurst, J. R., Maxwell, J. P., \& Harris, B. S. (2010). Athletic identity and aggressiveness: A cross- cultural analysis of the athletic identity maintenance model. International Journal of Sport and Exercise Psychology, 8(2), 99-116. https://doi.org/10.1080/1612197X.2010.9671936

Weinberg, R, \& Gould, D. (2007). Foundations of Sport And Exercise Psychology $\left(4^{\text {th }}\right.$ ed).Champaign: Human Kinetics.

Wilson, M., Smith, N., \& Holmes, P.S. (2007). The Role of Effort in Influencing the Effect of Anxiety on Performance: Testing the Conducting Predictions of Processing Efficiency Theory and the Conscious Processing Hypothesis. British Journal of Psychology, 98(3), 411-428. https://doi.org/10.1348/000712606X133047

Wong, E., Lox, C., \& Clark, S. (1993). Relation between Sports Context, Competitive Trait Anxiety, Perceived Ability, and Self-Presentation Confidence. Perceptual and Motor Skills, 76, 847-850. https://doi.org/10.2466/pms.1993.76.3.847 
Wyckoff, J. P. (2016). Aggression and emotion: Anger, not general negative affect, predicts desire to aggress. Personality and Individual Differences, 101, 220-226. https://doi.org/10.1016/j.paid.2016.06.001

\section{Postoje li razlike u sportskoj takmičarskoj anksioznosti i opštem sampoštovanju sportista u odnosu na pol i nivo fizičkog kontakta u sportu?}

Aleksandra A. Sanader', Jelena R. Petrović ${ }^{\text {(D) , Ljubica Bačanac³ }}$, Ivan Ivković ${ }^{4}$ Ivan Petrović ${ }^{2}$ iD i Olivera M. Knezević ${ }^{5}$

1 Zavod za sport i medicinu sporta Republike Srbije, Beograd, Srbija

2 Univerzitet odbrane, Vojna akademija, Beograd, Srbija

${ }^{3}$ Univerzitet Donja Gorica, Fakultet za sportski menadžment, Podgorica, Crna Gora

${ }^{4}$ Ministarstvo odbrane, Beograd, Srbija

${ }^{5}$ Univerzitet u Beogradu, Institut za medicinska instraživanja, Beograd, Srbija

\section{SAŽETAK}

Anksioznost se obično definiše kao negativno emocionalno stanje koje karakteriše nervosa, zabrinutost, uzrujanost, nesigurnost, bezrazlošan strah i koje generalno može imati štetne posledice po sportsko postignuće. Sa druge strane, vrsta sporta, kao i priroda i zahtevi određene sportske grane, takođe mogu biti povezani sa anksioznošću, bilo u formi crte ili stanja. Cilj rada je da utvrdi da li postoje razlike u prisustvu crte sportske takmičarske anksioznosti i opšteg samopoštovanja sportista u odnosu na pol i vrstu sporta (beskontaktni, kontaktni i kolizioni). Uzorkom je bilo obuhvaćeno 1024 mladih sportista (590 muškaraca i 434 žena). Nezavisne varijable su bile vrsta sporta i pol, a zavisne crta sportske takmičarske anksioznosti merena srpskom verzijom testa SCAT i opšte samopoštovanje mereno srpskom verzijom skale RSE. Podaci su obrađeni pomoću deskriptivne statistike, $\chi^{2}$ testa i MANOVA. Rezultati su pokazali da postoje statistički značajne razlike u crti sportske takmičarske anksioznosti u 
odnosu na pol, vrstu sporta i njihovu interakciju, dok razlika po pitanju opšteg samopoštovanja nije bilo. Može se zaključiti da u kolizionim sportovima, kod kojih je prisutan visok nivo anksioznosti nema nužno negativan efekat na kvalitet samog nastupa pa i rezultata. Podaci pokazuju da je nivo takmičarske anksioznosti uslovljen i polom i vrstom sporta, odnosno njihovom interakcijom. Dobijeni rezultati su od velikog značaja za psihološke dijagnostičke procedure i odabir adekvatne strategije prevladavanja takmičarskog stresa i anksioznosti kod sportista.

KIjučne reči: agresivnost, borilački sportovi, pol, samopoštovanje, stres 
